\title{
AIR POLLUTION TOLERANCE INDEX OF SOME SELECTED GYMNOSPERM SPECIES ALONG THE ROAD SIDE OF KATHMANDU VALLEY, NEPAL
}

\author{
Jaya Prakash Hamal* and Mukesh Kumar Chettri \\ Department of Botany, Amrit Science Campus \\ Tribhuvan University, Kathmandu, Nepal \\ *Email: jayahamal@gmail.com
}

\begin{abstract}
Response of plants towards air pollution is assessed by air pollution tolerance index (APTI). Four species of Gymnosperms (Thuja orientiales, Cedrus deodara, Pinus roxburghii and Araucaria bidwillii) were evaluated for APTI. Leaves were collected during winter season from polluted sites (Airport, Dhumbarahi, Jawalakhel, Ratnapark, and Sankhapark) and less polluted site (Narayanthan) of Kathmandu valley. Of four gymnosperm species collected from road side, all species (Cedrus deodara, Araucaria bidwillii, Thuja orientiales and Pinus roxburghii) showed high value of APTI (i.e., more than 8), indicating their resistance to air pollution.
\end{abstract}

Key words: Total chlorophyll content, Relative water content, Total ascorbic acid, Leaf extract, and $\mathrm{pH}$.

\section{INTRODUCTION}

Kathmandu has a pollution load in the air containing various pollutants like sulphur oxide, oxide of nitrogen, hydrocarbon, and particulates (Shrestha 2001). Rapid urbanization, industrialization, poor maintenance of road, poorly maintained vehicle deteriorate the air quality in Kathmandu valley (MaYa 2014). Bowl-shaped topography of Kathmandu valley restricts air movement and traps pollutants, and accelerates air pollution.

There are approximately 755,546 vehicles registered in the Bagmati Zone (DOTM 2014). The number of registered vehicles is rapidly increasing in Kathmandu, particularly, in the last five years accompanied with the rapid increase of urban population and economic development. The motorcycle has increased at an alarming rate of more than 20\% in the past five years (JICA 2012).

According to the Pollution Index Rate 2016 published by numbeo.com, a user-generated costof-living statistics website, Kathmandu was ranked at the $3^{\text {rd }}$ position with 96.60 pollution index (The Kathmandu Post, March 19, 2016). From the above it is clear that air of Kathmandu contains high amount of dust particles and causes adverse impacts on human health. Impacts of air pollution and dust on plants have largely been neglected. Therefore, in this study an attempt has been made to understand the impacts of pollution on different 
physiological parameters of some road side gymnosperms and their air pollution tolerance index.

\section{MATERIALS AND METHODS}

Kathmandu valley is located between $27^{\circ} 37^{\prime} 30^{\prime \prime} \mathrm{N}$ and $27^{\circ} 45^{\prime} 0^{\prime \prime} \mathrm{N}$ latitude, and $85^{\circ} 15^{\prime} 0^{\prime \prime}$ $\mathrm{E}$ and $85^{\circ} 22^{\prime} 30^{\prime \prime} \mathrm{E}$ longitude with $340 \mathrm{sq} \mathrm{km}$ area. The valley is bowl-like structure surrounded by high hills and the altitude of valley floor varies between $1300 \mathrm{~m}$ and $1400 \mathrm{~m}$. The prominent boundary features of the valley are Phulchowki Hill (2782 m) in South east, Shivapuri (2713 m) in North, Champa Devi (2400 m) in South West and Nagarjun $(2100 \mathrm{~m})$ in West.

A sub-tropical type of climate prevails in Kathmandu valley. The mean annual temperature in the Kathmandu valley is $18^{\circ} \mathrm{C}$. The coldest month is January with a mean temperature of $10^{\circ} \mathrm{C}$. The warmest months are July and August, with an average temperature of $24^{\circ} \mathrm{C}$. The valley has an annual rainfall of $1343 \mathrm{~mm}$. The wettest month is July with an average rainfall of about $378 \mathrm{~mm}$. December is the driest month, the average rainfall is less than 2 mm (www.nepal.climatemps.com/precipitation.php).

Polluted and less polluted sites were selected on the basis of frequency of movement of traffic vehicles. Experimental sites with high traffic areas like Airport, Dhumbarahi, and Sankhapark are along the ring road whereas experimental sites like Ratnapark and Jawalakhel are located inside ring road. Narayanthan was selected as a control site because of less traffic and less air pollution.

Leaf samples of Thuja orientiales, Cedrus deodara, Pinus roxburghii and Araucaria bidwillii were collected from different polluted and less polluted sites in winter (December-January). Fully matured leaves were collected in the morning around 9 to 10 am and brought to laboratory for physiological analysis.

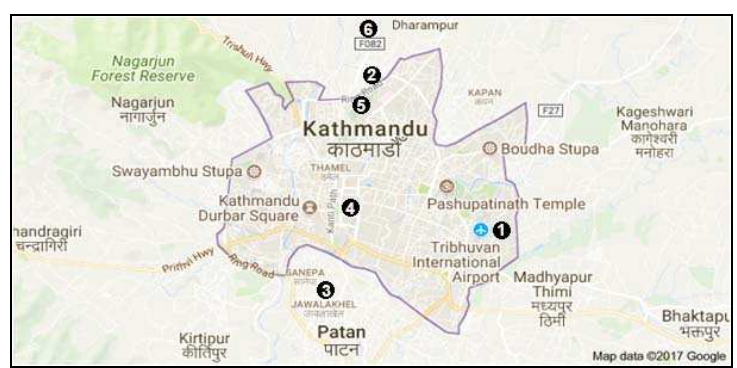

Fig. 1. Map of Study site: Kathmandu valley
1) Airport
2) Dhumbarahi,
3) Jawalakhel
4) Ratnapark,
5) Shankhapark
6) Narayanthan

\section{Estimation of relative water content (RWC)}

RWC was determined according to Barrs and Weatherly (1962). RWC is a ratio of the amount of water in the leaf tissue at sampling to that present when fully turgid. A composite sample of leaf discs was taken and the fresh weight was taken and then leaf was floated on water for up to $24 \mathrm{~h}$. The turgid weight was then recorded, and the leaf tissue was subsequently oven-dried to a constant weight at about $85^{\circ} \mathrm{C}$ for $24 \mathrm{~h}$. RWC is calculated by using the following formula:

$$
\text { RWC }(\%)=\frac{(\text { Fresh weight }- \text { dry weight })}{(\text { Turgid weight }- \text { dry weight }} \times 100
$$

\section{Chlorophyll}

Chlorophyll estimation was conducted according to Barnes et al. (1992). $0.05 \mathrm{~g}$ of leaves were cut in smaller pieces and placed in test tubes containing $5 \mathrm{ml}$ DMSO. Test tubes were incubated in a water bath at $60-65^{\circ} \mathrm{C}$ for an hour. From preliminary studies this time was judged satisfactory for the full decolorisation of tissues. Cooling at room temperature was followed for 30 min, filtration and absorption measured at $665 \mathrm{~nm}$ and $648 \mathrm{~nm}$ being the final stages. Blank determination was carried out with DMSO. Absorption measurement was carried out with a Spectrophotometer. 
Chlorophyll concentration ( $\mathrm{a}, \mathrm{b}$ and total) was expressed as $\mathrm{mg} / \mathrm{g}$ fresh weight and determined by the following formulae ${ }^{16}$ (Barnes et al. 1992).

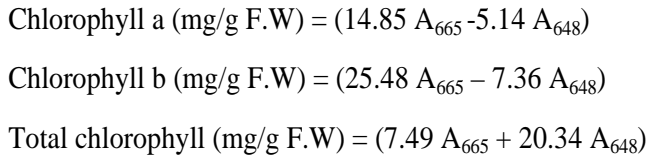

Where: $A_{665}=$ absorption value at $665 \mathrm{~nm}$ $\mathrm{A}_{648}=$ absorption value at $648 \mathrm{~nm}$

\section{Least extract pH}

Leaf-extract $\mathrm{pH}$ was determined with $\mathrm{pH}$ meter. Five $g$ of a leaf sample was crushed, and 50 $\mathrm{ml}$ deionized water was added, the obtained suspension was measured with a $\mathrm{pH}$ meter (Apriyantono et al. 1989).

\section{Ascorbic acid (AA)}

Ascorbic acid content (expressed in $\mathrm{mg} / \mathrm{g}$ ) was measured using spectrophotometric method (Bajaj and Kaur 1981). One $\mathrm{g}$ of the fresh foliage was taken, $4 \mathrm{ml}$ oxalic acid EDTA extracting solution was added to it, then one $\mathrm{ml}$ of Orthophospheric acid to it. $1 \mathrm{ml} 5 \%$ tetraoxosulphate acid was added to this mixture, and then $2 \mathrm{ml}$ of ammonium molybdate and $3 \mathrm{ml}$ of water was added. The solution is then allowed to stand for $15 \mathrm{~min}$ after which the absorbance at $760 \mathrm{~nm}$ is measured with a spectrophotometer. The concentrations of ascorbic acid in the sample then extrapolated from a standard ascorbic acid curve.

\section{Air Pollution Tolerance Index (APTI)}

APTI was calculated according to Singh and Rao (1983).

$$
\mathrm{APTI}=[\mathrm{A}(\mathrm{T}+\mathrm{P})+\mathrm{R}] / 10
$$

Where $\mathrm{A}=$ Ascorbic acid content $(\mathrm{mg} / \mathrm{g}), \mathrm{T}=$ total chlorophyll (mg/g), $\mathrm{P}=\mathrm{pH}$ of leaf extract and $\mathrm{R}=$ relative water content of leaf.

\section{Statistical analysis}

The data obtained from the above experiments were statistically analyzed using SPSS version 16 . ANOVA followed by Duncan's Multiple range test was conducted to understand significant differences (at $\mathrm{P}=0.05$ ) among different sites.

\section{RESULTS}

Total Chlorophyll in all four species (Pinus roxburghii, Thuja orientialis, Cedrus deodara and Araucaria bidwillii) showed reduction at one or two sites. Total chlorophyll content reduced significantly in Pinus at Ratnapark and Shankhapark. Similarly in total chlorophyll (TCH) was reduced in Thuja significantly at Shankhpark and Airport. In case of Cedurus TCH was reduced significantly $(\mathrm{P}=0.05)$ at Jawalakhel and Ratnapark area. total chlorophyll in Araucaria reduced in all sites than in Narayanthan, a control site.

Relative water content was significantly higher ( $\mathrm{P}$ $=0.05)$ at all polluted sites than in Narayanthan (Table 1). Almost similar pattern for RWC were observed in all species. In Pinus and Thuja highest RWC was observed at Dhumbarahi and Airport, respectively. But highest RWC was recorded at Ratnapark for both Cedrus and Araucaria.

pH of leaf extract was found to be increased significantly $(\mathrm{P}=0.05)$ in Pinus roxburghii at all studied polluted sites. In Thuja $\mathrm{pH}$ reduced significantly at Dhumbarahi. Inconsistent result was seen in Cedrus leaf $\mathrm{pH}$, in some sites (Ratnapark and Jawalakhel). At Airport, Dhumbarahi and Shankhapark significant decrease was observed in $\mathrm{pH}$ than in Narayanthan. In Araucaria, significant decrease in $\mathrm{pH}$ of leaf extract was observed at Jawalakhel.

Ascorbic Acid concentration in all species increased at most of the polluted sites than in less polluted site Narayanthan. Concentration of 
Ascorbic acid in Thuja orientialis increased significantly at all sites than in Narayanthan (control site). In Pinus, significant increase in Ascorbic Acid was recorded at Jawalakhal, Ratnapark and Shankhapark.
APTI values at all polluted sites were found to be higher than in less polluted site, Narayanthan. Among the studied gymnosperms, APTI value was recorded more than 8 in all gymnosperms, indicating their ability to withstand pollution.

Table 1. Mean value \pm standard deviation of total chlorophyll (TCH in $\mathrm{mg} / \mathrm{g}$ ), Relative water content (RWC in \%), pH, Ascorbic acid (AA in mg/g) and Air pollution tolerance index (APTI) of (A) Pinus roxburghii, (B) Thuja orientialis, (C) Cedrus deodara and (D) Araucaria bidwillii at different sampling sites of Kathmandu valley.

(A) Pinus roxburghii

\begin{tabular}{lccccc}
\hline Sites & $\mathbf{T C H} \pm$ SD & $\mathbf{R W C}$ & $\mathbf{p H}$ & $\mathbf{A A}$ & APTI \\
\hline Airport & $3.530 \pm 0.216 \mathrm{~B}$ & $83.470 \pm 8.909 \mathrm{CD}$ & $6.210 \pm 0.197 \mathrm{C}$ & $0.464 \pm 0.053 \mathrm{~A}$ & $8.801 \pm 0.943 \mathrm{~B}$ \\
Dhumbarahi & $3.736 \pm 0.617 \mathrm{~B}$ & $85.717 \pm 5.950 \mathrm{D}$ & $4.632 \pm 0.120 \mathrm{~B}$ & $0.445 \pm 0.057 \mathrm{~A}$ & $8.941 \pm 0.571 \mathrm{~B}$ \\
Jawalakhel & $3.645 \pm 0.111 \mathrm{~B}$ & $72.71 \pm 4.743 \mathrm{~B}$ & $6.160 \pm 0.089 \mathrm{C}$ & $0.843 \pm 0.088 \mathrm{~B}$ & $6.891 \pm 0.320 \mathrm{~A}$ \\
Ratnapark & $0.629 \pm 0.283 \mathrm{~A}$ & $77.161 \pm 4.831 \mathrm{BC}$ & $6.160 \pm 0.089 \mathrm{C}$ & $0.725 \pm 0.015 \mathrm{~B}$ & $7.505 \pm 0.804 \mathrm{~A}$ \\
Shankhapark & $0.684 \pm 0.47 \mathrm{~A}$ & $77.57 \pm 5.518 \mathrm{BC}$ & $6.160 \pm 0.089 \mathrm{C}$ & $0.832 \pm 0.065 \mathrm{~B}$ & $7.827 \pm 0.940 \mathrm{~A}$ \\
Narayanthan & $3.555 \pm 0.586 \mathrm{~B}$ & $61.36 \pm 5.428 \mathrm{~A}$ & $4.294 \pm 0.164 \mathrm{~A}$ & $0.485 \pm 0.160 \mathrm{~A}$ & $7.537 \pm 0.376 \mathrm{~A}$ \\
\hline
\end{tabular}

(B) Thuja orientialis

\begin{tabular}{lccccc}
\hline Sites & $\mathbf{T C H} \pm \mathbf{S D}$ & $\mathbf{R W C}$ & $\mathbf{p H}$ & $\mathbf{A A}$ & APTI \\
\hline Airport & $2.364 \pm 0.1234 \mathrm{AB}$ & $81.799 \pm 5.510 \mathrm{C}$ & $6.320 \pm 0.17889 \mathrm{~B}$ & $0.465 \pm 0.053 \mathrm{~B}$ & $8.447 \pm 0.637 \mathrm{C}$ \\
Dhumbarahi & $3.551 \pm 0.579 \mathrm{C}$ & $76.814 \pm 4.152 \mathrm{BC}$ & $5.300 \pm 0.27386 \mathrm{~A}$ & $0.424 \pm 0.848 \mathrm{~B}$ & $8.093 \pm 0.459 \mathrm{BC}$ \\
Jawalakhel & $3.665 \pm 0.181 \mathrm{BC}$ & $72.393 \pm 5.189 \mathrm{~B}$ & $6.464 \pm 0.25938 \mathrm{~B}$ & $0.716 \pm 0.1406 \mathrm{C}$ & $8.138 \pm 0.577 \mathrm{BC}$ \\
Ratnapark & $3.378 \pm 0.177 \mathrm{C}$ & $72.393 \pm 5.28 \mathrm{~B}$ & $6.564 \pm 0.03578 \mathrm{~B}$ & $0.695 \pm 0.067 \mathrm{C}$ & $7.597 \pm 0.641 \mathrm{ABC}$ \\
Shankhapark & $0.599 \pm 0.236 \mathrm{~A}$ & $73.824 \pm 6.45 \mathrm{~B}$ & $6.516 \pm 0.00894 \mathrm{~B}$ & $0.843 \pm 0.0516 \mathrm{D}$ & $6.939 \pm 2.109 \mathrm{AB}$ \\
Narayanthan & $3.295 \pm 0.585 \mathrm{BC}$ & $60.205 \pm 1.960 \mathrm{~A}$ & $6.520 \pm 0.05814 \mathrm{~B}$ & $0.305 \pm 0.098 \mathrm{~A}$ & $6.347 \pm 0.542 \mathrm{~A}$ \\
\hline
\end{tabular}

(C) Cedrus deodara

\begin{tabular}{lccccc}
\hline Sites & $\mathbf{T C H} \pm$ SD & $\mathbf{R W C}$ & $\mathbf{p H}$ & $\mathbf{A A}$ & APTI \\
\hline Airport & $3.128 \pm 0.461 \mathrm{C}$ & $72.136 \pm 3.361 \mathrm{AB}$ & $4.104 \pm 0.058 \mathrm{~A}$ & $0.383 \pm 0.041 \mathrm{~A}$ & $6.677 \pm 1.079 \mathrm{~A}$ \\
Dhumbarahi & $3.232 \pm 0 . .413 \mathrm{C}$ & $79.168 \pm 6.984 \mathrm{CD}$ & $4.128 \pm 0.071 \mathrm{~A}$ & $0.882 \pm 0.041 \mathrm{C}$ & $7.856 \pm 1.291 \mathrm{AB}$ \\
Jawalakhel & $1.085 \pm 0.132 \mathrm{~A}$ & $84.827 \pm 4.976 \mathrm{CD}$ & $5.664 \pm 0.371 \mathrm{C}$ & $0.803 \pm 0.067 \mathrm{~B}$ & $8.907 \pm 0.800 \mathrm{~B}$ \\
Ratnapark & $0.672 \pm 0.0598 \mathrm{~A}$ & $85.435 \pm 4.128 \mathrm{D}$ & $5.764 \pm 0.147 \mathrm{C}$ & $0.814 \pm 0.049 \mathrm{~B}$ & $8.705 \pm 0.414 \mathrm{~B}$ \\
Shankha park & $3.474 \pm 0.242 \mathrm{C}$ & $78.168 \pm 6.984 \mathrm{BC}$ & $4.128 \pm 0.071 \mathrm{~A}$ & $0.882 \pm 0.041 \mathrm{C}$ & $7.876 \pm 1.283 \mathrm{AB}$ \\
Narayanthan & $2.169 \pm 0.960 \mathrm{~B}$ & $66.403 \pm 2.002 \mathrm{~A}$ & $4.480 \pm 0.268 \mathrm{~B}$ & $0.384 \pm 0.042 \mathrm{~A}$ & $7.096 \pm 0.556 \mathrm{~A}$ \\
\hline
\end{tabular}


(D) Araucaria bidwillii

\begin{tabular}{lccccc}
\hline Sites & TCH \pm SD & RWC & pH & AA & APTI \\
\hline Airport & $0.812 \pm 0.138 \mathrm{~A}$ & $86.292 \pm 4.233 \mathrm{C}$ & $6.356 \pm 0.149 \mathrm{~B}$ & $0.644 \pm 0.130 \mathrm{~B}$ & $8.861 \pm 0.694 \mathrm{C}$ \\
Dhumbarahi & $2.759 \pm 0.352 \mathrm{~B}$ & $85.492 \pm 5.461 \mathrm{C}$ & $6.260 \pm .000 \mathrm{~B}$ & $0.644 \pm 0.130 \mathrm{~B}$ & $7.026 \pm 1.417 \mathrm{~B}$ \\
Jawalakhel & $0.8011 \pm 0.043 \mathrm{~A}$ & $72.709 \pm 7.337 \mathrm{~B}$ & $5.776 \pm 0.251 \mathrm{~A}$ & $0.302 \pm 0.064 \mathrm{~A}$ & $5.404 \pm 0.581 \mathrm{~A}$ \\
Ratnapark & $0.599 \pm 0.207 \mathrm{~A}$ & $88.292 \pm 4.233 \mathrm{C}$ & $6.248 \pm 0.026 \mathrm{~B}$ & $0.711 \pm 0.052 \mathrm{~B}$ & $8.648 \pm 0.805 \mathrm{C}$ \\
Shankha park & $0.650 \pm 0.196 \mathrm{~A}$ & $86.892 \pm 2.993 \mathrm{C}$ & $6.248 \pm 0 . .026 \mathrm{~B}$ & $0.644 \pm 0.130 \mathrm{~B}$ & $8.963 \pm 0.777 \mathrm{C}$ \\
Narayanthan & $3.596 \pm 0.611 \mathrm{C}$ & $52.898 \pm 2.389 \mathrm{~A}$ & $6.336 \pm 0.187 \mathrm{~B}$ & $0.245 \pm 0.509 \mathrm{~A}$ & $5.576 \pm 0.514 \mathrm{~A}$ \\
\hline
\end{tabular}

Identical letters following the mean value $\pm \mathrm{SD}$ in the vertical column (for each plant species) denote no significance difference among sites at $\mathrm{P}=0.05$ by Duncan's multiple range test followed after ANOVA.

\section{DISCUSSION}

Air pollution tolerant index (APTI) is an index that shows capability of a plant to tolerate air pollution. Plants which have higher index value are tolerant to air pollution and can be used to with stand pollution, while plants having low index value show less tolerance and can be used to indicate levels of air pollution (Singh and Rao 1983). All gymnosperm plants under present study showed high APTI value at polluted sites indicating their ability to combat air pollution. To understand APTI value, different physiological parameters like chlorophyll content, ascorbic acid, relative water content and $\mathrm{pH}$ were considered. To understand the physiological phenomena related with air pollution tolerance in plant, the above mentioned parameters are discussed below.

Chlorophyll content of plants determines its photosynthetic activity as well as the growth and development of biomass. The chlorophyll content of plant differs from species to species with the age of leaf and also with the pollution level (Katiyar and Dubey 2001). Present study showed that chlorophyll content in all the plants varies with the pollution status of the area. It also varies with the tolerance as well as sensitivity of the plant species, i.e., higher the sensitive nature of the plant species lower the chlorophyll content. High total chlorophyll content was observed in Pinus roxburghii even in polluted site and these may be due to its tolerance nature (Beg et al. 1990, Jyothi and Jaya 2010).
Ascorbic acid is regarded as an antioxidant found in plants, and influences resistance to a adverse environmental condition including air pollution (Keller and Schwager 1977, Lima et al. 2000). Ascorbic acid (AA) is a strong reducing agent and it activates many physiological and defence mechanism. Its reducing power is directly proportional to its concentration (Raza and Murthy 1988, Lewis 1976). Being a very important reducing agent, ascorbic acid also plays a vital role in cell wall synthesis, defense and cell division (Conklin 2001). Present study showed increase in the concentration of ascorbic acid in polluted with respect to the control site in all studied gymnosperms- Araucaria bidwillii, Thuja orientialis, Cedrus deodar and Pinus roxburghii. Increase in ascorbic acid may be due to the increased rate of production of reactive oxygen species (ROS) during photo-oxidation of $\mathrm{SO}_{2}$ to $\mathrm{SO}_{3}$ (Chaudhary and Rao 1977) or other pollutants. These acids may bind toxic metals in large quantity and help in defence mechanism. Thus higher ascorbic acid content of the plant can be considered as a sign of its tolerance against the pollutants.

Leaf extract $\mathrm{pH}$ increased at different sites in the present study. High $\mathrm{pH}$ may increase the efficiency of conversion from hexose sugar to Ascorbic acid, while low leaf extract $\mathrm{pH}$ showed good correlation with sensitivity to air pollution 
(Escobedo et al. 2008, Pasqualini et al. 2001). Scholz and Reck (1977) have reported that in presence of an acidic pollutant, the leaf $\mathrm{pH}$ is lowered and the decline is greater in sensitive species. A shift in cell sap $\mathrm{pH}$ towards the acid side in presence of an acidic pollutant might decrease the efficiency of conversion of hexose sugar to ascorbic acid. However, the reducing activity of ascorbic acid is $\mathrm{pH}$ dependent being more at higher and lesser at lower $\mathrm{pH}$. Hence increase in the leaf extract $\mathrm{pH}$ gives tolerance to plants against pollution.

Only Pinus roxburghii showed significant increase in leaf extract $\mathrm{pH}$ level as compare to less polluted site Narayanthan. Other studied plants showed insignificant difference or decrease in $\mathrm{pH}$ indicating possibility of presence of acidic pollutants in the atmosphere. There are so many factors controlling tolerance in plants. Plants with lower $\mathrm{pH}$ are more susceptible, while those with $\mathrm{pH}$ around 7 are more tolerant (Bakiyaraj and Ayyappan 2014). From this statement Cedrus deodara is more susceptible and others are comparatively more tolerant species.

Relative water content in Pinus roxburghii, Thuja orientiales, Cedrus deodara, and Araucaria bidwillii increased significantly $(\mathrm{P}=0.05)$ in all polluted sites than in less polluted site, Narayanthan. Water is crucial prerequisite for plant life. High RWC favours drought resistance in plants (Swami et al. 2004). High water content within plant body possibly helps to maintain its physiological balance under stress condition such as exposure to air pollution when the transpiration rates are usually high. It also serves as an indicator of drought resistance in plants. Relative water content (RWC) of a leaf is the water present in it relative to its full turgidity. Relative water content is associated with protoplasmic permeability in cells causeing loss of water and dissolved nutrients, resulting in early senescence of leaves (Agrawal and Tiwari 1997). High relative water content in plants under polluted condition might be an strategy of tolerant species of plants to withstand pollutants.

From the study it can be concluded that Pinus roxburghii, Thuja orientiales, Cedrus deodara and Araucaria bidwillii have high APTI and hence they can withstand air pollution along the roads in Kathmandu. These plants mostly adjusted their physiology by increasing total chlorophyll content, ascorbic acids content, $\mathrm{pH}$ and relative water content.

\section{REFERENCES}

Abida, B. and S. Harikrishna. 2010. Evaluation of some tree species to absorb air pollutants in three industrial locations of South Bengaluru, India. E-Journal of Chemistry 7(S1):51-56.

Agrawal, S. and S.L. Tiwari. 1997. Susceptibility level of few plants on the basis of air pollution tolerance index. Indian Forester 1(2):319-322.

Apriyantono, A., D. Fardiaz, N.L. Puspitasari and B.S. Sedarnawati.1989. Analysis Pangan. Bogor: IPB Pr.

Bajaj, K.L. and G. Kaur. 1981. Spectrophoto metric determination of Ascorbic Acid in vegetation and fruits. Analyst 106:117-120.

Bakiyaraj, R. and D. Ayyappan. 2014. Air pollution tolerance index of some terrestrial plants around an industrial area. International Journal of Modern Research and Reviews 2:17.

Barnes, J.D., L. Balaguer, E. Manrique, S. Elvira and A.W. Davison. 1992. A reappraisal of the use of DMSO for the extraction and determination of chlorophylls $\mathrm{a}$ and $\mathrm{b}$ in lichens and higher plants. Environ. Exp. Bot. 32:85-100.

Barr, H.D. and P.E. Weatherley. 1962. A reexamination of the relative turgidity technique for estimating water deficit in leaves. Aust. J. Biol. Sci. 15:413-428.

Beg, M.U., M.H. Farooq, S.K. Bhargava, M.M. Kidwai and M.M. Lal. 1990. Performance of trees around a thermal power station. Environ. Ecol. 8:791-797. 
Chaudhary, C.S. and D.N. Rao. 1977. Study of some factors in plants controlling their susceptibility to sulphur dioxide pollution. Proc. Ind. Natl. Sci. Acad. Part B., 46:236241.

Conklin, P.L. 2001. Recent advances in the role and biosynthesis of ascorbic acid in plants. Plant Cell Environ. 24:383-394.

DOTM, Government Nepal. 2014. https:/www.dotm.gov.np/aploads/files/details_ of_Registration_of_Transport_Type.

Escobedo, F. J., D.J. Wagner, C.L. Nowak, D.L. Maza, M. Rodrigyez and D.E. Crane. 2008. Analysing the cost effectiveness of Santiago, Chiles policy of urban forests to improve air quality. J. Environ. Biol. 29:377-379.

JICA (Japan International Cooperation Agency). 2012. Data Collection Survey on Traffic Improvement in Kathmandu Valley. Final report submitted to Ministry of Physical Planing works and transport Management, Development of Roads, Government of Nepal. $92 \mathrm{pp}$

Jyothi S.J. and D.S. Jaya. 2010. Evaluation of air pollution tolerance index of selected plant species along roadside in Thiruvananthpuram, Kerala. J. Environ. Bio. 31:379-386.

Katiyar, V. and P.S. Dubey. 2001. Sulphur dioxide sensitivity on two stage of leaf development in a few tropical tree species. Ind. J. Environ. Toxicol. 11:78-81.

Keller, Th. and H. Schwager. 1977. Air pollution and ascorbic acid. European J. Forest Pathology 7:338-350.

Lewis, S. 1976. Vitamin C: Its Molecular Biology and Medical Potential. Academic Press, London.

Lima, A.S., R.M. Alegre and A.J.A. Meirelles. 2000. Partitioning of pectinolyticenzymes in polyethylene glycol/potassium phosphate aqueous two-phase systems. Carbohydrate Polymers 50:63-68.

MaYa (Manav-Kendrit Yatayat Abhiyan). 2014. A Factsheet \# 5. air quality status and
Management in Kathmandu valley. Clean Energy Nepal and UN Habitat. pp. 8.

Pasqualini, S., P. Batini, L. Ederli, A. Porceddu, C. Piccioni, F. DE Marchis and M. Antonielli. 2001. Effects of short-term ozone fumigation on tobacco plants: Response of the scavenging system and expression of the glutathione reductase. Plant Cell Environ. 24:245-252.

Raza, S.H. and M.S.R. Murthy. 1988. Air pollution tolerance index of certain plants of Nacharam Industrial Area, Hyderabad. Indian J. Bot. 11(1):91-95.

Scholz, F. and S. Reck. 1977. Effects of acids on forest trees as measured by titration in vitro inheritance of buffering capacity in PiceaAbies. Water, Air and Soil Pollut. 8:41-45.

Shakya, K., M.K. Chettri and Thomas Sawidis. 2012. Use of mosses for the survey of heavy metal deposition in ambient air of the Kathmandu valley applying active monitoring technique. Ecoprint 19:17-29.

Shrestha, B. 2001. Air Pollution Status Kathmandu, Nepal. Air pollution in the mega cities of Asia, 3-5 September 2001, Seoul, Korea.

Shrestha, R.M. and A.K. Raut. 2002. Air quality in Kathmandu. Air quality in Asian and Pacific cities (BAQ, 2002) $16^{\text {th }}$ December 2002-18 December 2002. Honkong Conversion and Exhibition Centre (HK CEC).

Singh, S.K. and D.N. Rao. 1983. Evaluation of plants for their tolerance to air pollution. In: Proc. Symp. on Air Pollution Control held at IIT, Delhi. pp. 218-224.

Swami, A., D. Bhatt and P.C. Joshi. 2004. Effects of automobile pollution on sal (Shorea robusta) and rohini (Mallotus phillipinensis) at Asarori, Dehradun. Himalayan Journal of Environment and Zoology 18(1):57-61.

The Kathmandu Post. 2016. Kathmandu: The third most polluted city in the world. The Kathmandu Post, March 19, 2016, Kantipur Publication. 